\title{
Model of Sustainable Business for Business-Evidence for Taiwan
}

\author{
Kuo-Chung Huang and Chang-Wen Chen
}

\begin{abstract}
This study presents the model of sustainable business for business that integrates many ideas of scholars with gains of this study. It shows that nowadays enterprises should have social practice and economic practice for their managial idea and goal, and merges both into managerial policy to get the achievement of sustainable business. It describes the interreaction of social performance and financial performance, influence degree got from operating variables. In addition to ordinary least squares model (OLS), this paper uses the research approach of three-stage least squares model (3SLS) for considering endogeneous variables. Then we can construct the unbias, consistency and validity model, and offer companies the bases of business decision. From empirical results, this paper shows that more operating variables are significant influence on social performance and financial performance, and there is the positive and apparent influence for corporate social performance on corporate financial performance. The financial performance has positive influence on social performance too, and shows that the good financial performance contributes to the push of corporate social practice. These offer good foundation for business to construct the model of sustainable business. While getting profit, business can facilitate the progress of social responsibility.
\end{abstract}

Index Terms-Sustainable business, corporate practices, corporate social responsibility, corporate social performance, corporate financial performance, stakeholder, endogeneous, economic.

\section{INTRODUCTION}

Scholar suggested that corporate operation has impact on society and environment [1], and everybody is worry about the globalization of enterprises. The executive chairman of enterprise can't only regard corporate social responsibility (CSR) as the secondary problem, but indispensable part for enterprises operation. He emphasized that CSR should be the key operation tactics. The corporate performance is not only weighed with financial profits, and must give consideration to the impact on environment, contribution to the society. It becomes critical to explore if CSR investment actually increase corporate value and profitability, or will only burden the corporate cost and reduction of competitiveness. It becomes a judicious operating strategy for company to meet the expectations and needs of social responsibility, while pursuing maximization of corporate value and profitability. That is also a foundation of sustainable operating for company to do both well. Enterprises should practically ponder over the values of sustainable business, regard enterprise's social performance as intangible social assets, and integrate social performance and financial performance to produce the comprehensive performance of sustainable operation.

\section{LITERATURE REVIEW}

\section{A. Meaning of Corporate Social Responsibility}

Corporate commitment to social responsibility should include employee health and well-being, product quality, process, equipment, production environment, profit-making chance lasting improvement, sustainable operating and development [2]. Paying attention to stakeholder in the procedure of organizational operation to minimize the negative impact and maximize the positive influence [2], [3].

\section{B. Measurement of Corporate Social Performance}

Corporate social performance (CSP) measurement in the literature can be divided into three dimensions: (1) the degree of social matters of interest to disclose, measureing business-to-the public disclosures content analysis [4]; (2) corporate social responsibility initiatives, such as philanthropy, social owed programs, and pollution control etc., measurement methods can be the questionnaire analysis for employees and managers [5]; (3) corporate image, reputation, and social index rating,etc., measurement approach can be processed by the third independent rating party, such as the KLD index, Fortune business magazine, Moskowitz Prize, and Business Ethics Publications [6].

\section{Measurement of Corporate Financial Performance}

Traditional effectiveness of business is corporate financial performance (CFP), and it is composed of two measurement indicators for CFP: Stock Market-Based measurement and Accounting-Based measurement. The stock market-based is based on the use of market views and stock value, can use firm value TobinQ as measurement tool, and accounting-based is the use of earnings, can use Return On Assets (ROA) as measurement tool.

\section{Relation of Social Performance and Financial Performance}

It is inconclusive for findings on the relationship between CSP and CFP, existing positive relationship [6], [7]; negative relationship [8], [9]; and no relationship [10]. This study will be careful to examine their relationship with OLS model and 3SLS model.

\section{RESEARCH APPROACH}

Kuo-Chung Huang and Chang-Wen Chen are with Department of Business Administration,Nanhua University (e-mail: kchuang.tw@gmail.com, jwchen@wfu.edu.tw). 
social performance and financial performance described above, we can develop theoretical models for this study.

\section{A. Model of Sustainable Business}

Scholars suggested it is a important managerial tool to process affairs of stakeholder, and be able to turn CSR into managerial practices and strategies [11]. Scholars explored the content of CSR with four dimensions including economic, legal, moral, and philanthropic aspects [12], [13]. Scholars divided the concept of managers' social responsibility into: (1) the traditional economy, only pay attention to corporate economic benefits; (2) the social economy, focus on how to bring in financial benefits derived from social performance; (3)the philanthropy, consider to unconditionally burden the social responsibility; (4) the modern charity, to consider social responsibility as a charitable act, and make companies bring in additional economic benefits; (5) the modern strategy, incorporate social responsibility into business strategy to create a win-win model of sustainable business.[14]

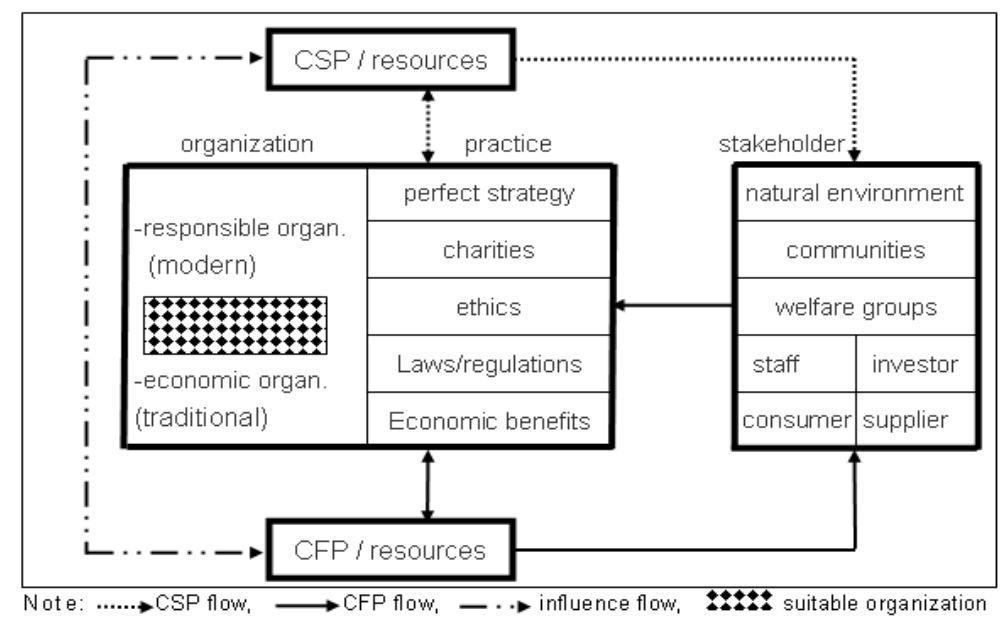

Fig. 1. Model of sustainable business for business

In Fig. 1 listed above, the sustainable model contains the essence being from a number of scholars and author, all together construct the operating content and process. In the model, corporate practices can be divided into (a) economic practice, corporate put resources into operation in this practice, focusing on the upgrading of the traditional economy, and produce financial performance; (b) social practice, companies put part of the resources into this practice bearing socoial responsibility, and have social performance. If company can incorporate the social practice in the economic decision-making, thus the social performance produced contributes to the promotion of financial performance even more, then the company is a modern responsible organization. If companies seldom have a burden of social responsibility, do not also pay attention to social responsibility, this company is still in the traditional economic organization, the company only works hard with operating-profit. Therefore, there is a continuous area of organization in the Fig. 1 between modern and tradition, which organization type is more suitable, depending on business culture and values; (c) that relationship and direction existing in stakeholders, corporate practices and performance are shown by flow chart in Fig. 1. Companies invest resources into corporate practices, produce performance of corporate practices, and constribute some resources to stakeholders so as to stakeholders have feelings and action, then give good feedback for the corporate pracitces so that business operating can be eldless and sustainable. From the describtion above, this study intends to explore the influence factors and relationship of social performance and financial performance.

\section{B. Research Model}

This study uses three-stage least squares method to explore the endogeneous relation of multiple variables. It can avoid producing bias and inconsistent estimator, and get the model structure of validity and consistency. We also use OLS method to verify the empirical results got from 3SLS. The empirical relational models for this study listed below:

$\mathrm{CSP}=\mathrm{f}($ TobinQ, MAN, MAN2, INSTH, BR, ROI, INV, SIZE)

TobinQ $=\mathrm{f}(\mathrm{CSP}, \mathrm{MAN}, \mathrm{BR}, \mathrm{OPR}, \mathrm{ROI}, \mathrm{DEBT}, \mathrm{RD}, \mathrm{IND})$

\section{TEJ Dataset}

The dataset of this study is sourced from the Economic Journal database, which includes profile, company, finance, equity, and governance datasets. All of the datasets provide the basic data, finance data, and stock price data of listed companies and public offering companies. For verification, this study collects the financial data of the 200 public offering companies listed in the Taiwan Stock Exchange (TSE) and Over the Counter (OTC) in 2006 to 2010, which includes 13 attribures, and other one variable from CommanWealth magazine described below.

\section{Variables}

The main variable of this study is CSP, measured by using the result of surveying "corporate citizenship" by CommonWealth magazine [1]. This study analyzes two endogeneous variables of CSP and TobinQ for CFP. There are ten exogeneous variables in the study: MAN is managerial ownership ratio. MAN2 is the square of managerial ownership ratio. INSTH is the shareholding ratio of institution. OPR is operating leverage. ROI is ratio of 
stock returns. BR is systematic risk, representing individual asset return correlated with the market return. DEBT is debt ratio. RD is research \& development expenditures. INV is intensity of investment. IND represents high-tech and non high-tech industry. SIZE is firm size.

\section{E. Hypotheses}

Hypothesis established in this study is: There is positive interaction causal relationship between social performance and financial performance.

Enterprises with good financial performance have more ability to perform social practice to get a better social performance. It is namely available funds hypothesis, scholars supported this hypothesis [9]. Enterprises with high social performance have good social image, thereby stakeholders will take concrete action to support, and thus enhance the company's financial performance. It is namely social impact hypothesis, scholars support this hypothesis [15].

\section{EMPIRICAL RESULTS AND ANALYSIS}

\section{A. OLS Regression Model}

TABLE I: OLS REGRESSION MODEL FOR CSP / TOBINQ

\begin{tabular}{|l|l|l|l|}
\hline \multirow{2}{*}{ Exo.var. } & \multicolumn{1}{|c|}{ Social performance model } & \multirow{2}{*}{ Endo. Var. } & \multicolumn{1}{|c|}{ Financial performance model } \\
\cline { 2 - 3 } & \multicolumn{1}{|c|}{ CSP } & Exo. Var. & TobinQ \\
\hline intercept & $-0.9615(-3.4232 / 0.0008)^{* * *}$ & intercept & $1.3193(5.3015 / 0.0000)^{* * *}$ \\
\hline TobinQ & $0.0711(1.8888 / 0.0604)^{*}$ & CSP & $0.3217(3.4151 / 0.0008)^{* * *}$ \\
\hline MAN & $0.0148(2.4431 / 0.0155)^{* *}$ & MAN & $-0.0022(-0.6826 / 0.4957)$ \\
\hline MAN2 & $-0.0219(-2.7998 / 0.0056)^{* * *}$ & BR & $0.2697(1.4603 / 0.1459)$ \\
\hline INSTH & $0.0021(1.0229 / 0.3077)$ & OPR & $-0.0055(-1.7091 / 0.0891)^{*}$ \\
\hline BR & $-0.3778(-3.3200 / 0.0011)^{* * *}$ & ROI & $0.0075(8.3776 / 0.0000)^{* * *}$ \\
\hline ROI & $-0.0016(-2.7319 / 0.0069)^{* * *}$ & DEBT & $-0.0232(-7.3708 / 0.0000)^{* * *}$ \\
\hline INV & $0.0055(1.1115 / 0.2677)$ & RD & $0.0213(1.5135 / 0.1318)$ \\
\hline SIZE & $0.1372(5.0315 / 0.0000)^{* * *}$ & IND & $0.3572(3.4204 / 0.0008)^{* * *}$ \\
\hline R-squared & 0.369253 & R-squared & 0.4669 \\
\hline Adjusted R-squared & 0.342834 & Adjusted R-squared & 0.4446 \\
\hline
\end{tabular}

Note: Cell indicated : coef.(t-stat./p-value) ; $: \alpha \leqq 0.10 \quad * *: \alpha \leqq 0.05 \quad * * *: \alpha \leqq 0.01 \alpha$ : significant level

Numbers of operational variables have significant impact on financial performance and social performance in Table I listed above. Social performance and financial performance have significantly positive influence each other. That is consistent with "the hypothesis".

\section{B. 3SLS Simultaneous Equations Model}

From the following 3SLS simultaneous equations in Table 2 listed below, we can get the relationships of social performance, financial performance and other key factors.

TABLE II: 3SLS MODEL FOR CSP - TOBINQ

\begin{tabular}{|l|l|l|l|}
\hline \multirow{2}{*}{ Exo.var. } & \multicolumn{2}{|c|}{ Endo. Var. } & Financial performance model \\
\cline { 2 - 3 } & CSP & Exo. Var. & TobinQ \\
\hline intercept & $-0.8281(-2.9689 / 0.0032)^{* * *}$ & intercept & $1.1256(4.2028 / 0.0000)^{* * * *}$ \\
\hline TobinQ & $0.0342(0.5496 / 0.5829)$ & CSP & $0.5450(3.3830 / 0.0008)^{* * *}$ \\
\hline MAN & $0.0122(2.0940 / 0.0369)^{* *}$ & MAN & $-0.0021(-0.6615 / 0.5087)$ \\
\hline MAN2 & $-0.0204(-2.7348 / 0.0065)^{* * *}$ & BR & $0.3386(1.8202 / 0.0695)^{*}$ \\
\hline INSTH & $0.0041(1.9877 / 0.0476)^{* *}$ & OPR & $-0.0058(-1.8694 / 0.0623)^{*}$ \\
\hline BR & $-0.3524(-3.1516 / 0.0018)^{* * *}$ & ROI & $0.0078(8.6256 / 0.0000)^{* * *}$ \\
\hline ROI & $-0.0014(-2.0652 / 0.0396)^{* *}$ & DEBT & $-0.0227(-7.4012 / 0.0000)^{* * * *}$ \\
\hline INV & $0.0040(0.8501 / 0.3958)$ & RD & $0.0263(1.9299 / 0.0544)^{*}$ \\
\hline SIZE & $0.1207(4.5809 / 0.0000)^{* * *}$ & IND & $0.330715(3.2866 / 0.0011)^{* * * *}$ \\
\hline R-squared & 0.363571 & R-squared & 0.450924 \\
\hline Adjusted R-squared & 0.336914 & Adjusted R-squared & 0.427926 \\
\hline
\end{tabular}

Note: Cell indicated: coef.(t-stat./p-value) ; $: \alpha \leqq 0.10 \quad * *: \alpha \leqq 0.05 \quad * * *: \alpha \leqq 0.01 \quad \alpha$ : significant level

1) The Results and discussion for the social performance in 3SLS model

From social performance model in Table II, we can get results and discussion: (a) CFP has positive influence on CSP but not significant. It facilitates the implementation of social responsibility, and being consistent with "the hypothesis". (b) Managerial shareholding and social performance has significantly non-linear relationship, and as concave down quadratic curve. The results explain that business managers enhance CSP in order to promote CFP 
and consolidate business powers as the same time. (c) Institutional ownership has a significant positive influence on social performance. It shows that institutional ownership with the socially responsible investment makes more businesses to promote social performance. (d) Companies with the greater systematic risk will reduce their social behavior to promote financial performance, so that system risk has a significant negative impact on social performance. (e) Business only exhausted resources to improve financial performance and ignored social responsibility to make a significant negative influence for return of stock on social performance. Companies with large-scale have the ability and willingness to do more in social responsibility to get better social performance.

2) The results and discussion for the financial performance in $3 S L S$ model

From financial performance model in Table II, we can get results and discussion: (a) CSP has significant positive impact on CFP. The companies with high social performance have more support and encourage the socially responsible investment to promote financial performance. That is consistent with "the hypothesis". (b) For the greater systematic risk the company can only try to do the best for financial performance. So systemic risk has a positive effect on financial performance. (c) Returns on stock investment and industry types were significant positive effect on financial performance, namely the better stock price promotes the corporate value. Because high-tech companies with incentives from the government have better operating environment and resources, they would boost the level of financial performance. (d) Liabilities increase the financial risk to reduce the investment and making-profit opportunities. So debt ratio has a significant negative effect on financial performance.

\section{CONCLUSION}

This paper proposes the sustainable business model for the basis of business philosophy and practices. For the empirical results, numbers of operational variables have significant impact on CFP and CSP. Social performance has significantly positive impact on financial performance. It shows that the implementation of corporate social responsibility play for an essential asset for creating a sustainable business model, and a new strategy to enhance financial performance. Therefore, enterprises should consider the business strategy of dual objectives to merge corporate social performance into corporate financial performance. Let the dual objectives get the best integration and interoperability to make enterprises attain sustainable business and development. There is positive interaction relation between social performance and financial performance, and that facilitates the progress of creating the model of sustainable business for business. Companies have different attributes and business culture, so doing dynamic adjustment for the weight and content of financial performance and social performance to meet the requirements of business cultures. It can ensure sustainable business for business and satisfy all stakeholders.

\section{REFERENCES}

[1] CommonWealth magazine editorial staff: The corporate citizen TOP 50, CommonWealth magazine, vol. 367, pp. 118-127, 2007.

[2] F. Maon, A. lindgreen, and V. Swaen, "Designing and implementing Corporate Social Responsibility: An integrative Framework grounded in Theory and practices," Journal of Business Ethics, vol. 87, pp. 71-89, 2009.

[3] Maignan, Isabelle, and O. C. Ferrell, "Corporate Citizenship as a Marketing Instrument: Concepts, Evidence, and Research Directions," European Journal of Marketing, vol. 35, no. 3/4, pp. 457-484, 2001.

[4] M. Orlitzky, F. L. Schmidt, and S. L. Rynes, "Corporate Social and Financial Performance: A Meta Analysis," Organization Studies, vol. 24, no. 3, pp. 403-441, 2003.

[5] C. R. Carter, R. Kale, and C. M. Grimm, "Environmental Purchasing and Firm Performance: An Empirical Investigation," Transportation Research, vol. 36, pp. 219-228, 2000.

[6] K. E. Schnietz and M. J. Epstein, "Exploring Financial Value of a Reputation for Corporate Social Responsibility During a Crisis," Corporate Reputation Review, vol. 7, no. 4, pp. 327-345, 2005.

[7] A. Lindgreen, V. Swaen, and W. J. Johnston, "Corporate Social Responsibility- An Empirical Investigation of U.S. Organizations," Journal of Business Ethics, vol. 85, pp. 303-323, 2009.

[8] A. McWilliams and D. Siegel, "Corporate social responsibility and financial performance: Correlation or misspecification?" Strategic Management Journal, vol. 21, no. 5, pp. 603-609, 2000.

[9] G. Moore, "Corporate Social and Financial Performance: An Investigation in the U.K. Supermarket Industry," Journal of Business Ethics, vol. 34, no. 3-4, pp. 299-315, 2001.

[10] G. Balabanis, H. C. Philips, and J. Lyall, "Corporate Social Responsibility and Economic Performance in the Top British Companies: Are They Linked?" European Business Review, vol. 98, no. 1, pp. 25-42, 1998.

[11] R. E. Freeman and W. M. Evan, "corporate governance: A stakeholder interpretation," Journal of Behavioral Economics, vol. 19, no. 4, pp. 337-359, 1990.

[12] A. B. Carroll, "Corporate Social Responsibility," Business and Society, vol. 38, no. 3, pp. 268-295, 1999.

[13] B. Ramasamy and M. Yeung, "“Chinese Consumers' Perceptionof Corporate Social Responsibility (CSR)," Journal of Business Ethics, vol. 88, no. 1, pp. 119-132, 2009.

[14] D. Jamali, Y. Sidani, and K. Asmar, "A three Country Comparative Analysis of Managerial CSR perspectives: Insights from Lebanon, Syria and Jordan," Journal of Business Ethics, vol. 85, pp. 173-192, 2009.

[15] L. E. Preston and D. P. O'bannon, "The Corporate Social-Financial Performance Relationship: A Typology and Analysis," Business \& Society, vol. 36, no. 4, pp. 419-429, 1997.

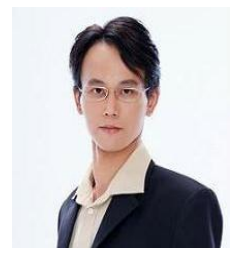

Kuo-Chung Huang is a professor of Department of Business Administration at Nanhua University, Taiwan. He received his Ph.D. degree from the Department of Management Sciences at Tamkang University, Taiwan. His research interests are in the fields of Management Sciences, Sampling Theory, and Statistical Analysis.

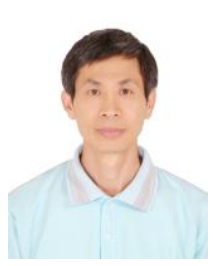

Chang-Wen Chen is a Lecturer of Department of Tourism and Leisure Management at WuFeng University of Science \& Technology and Ph.D. Student in the Department of Business Administration at Nanhua University. He received Bachelor of Engineering from National Cheng Kung University and Master of Industrial Management from National Taiwan University of Science and Technology. His main fields of academic research are Corporate Social Responsibility, Sustainable Development Model of Corporate Practice, and Tourism \& Leisure Management Information System. 